\title{
„Po prostu pracowałam” Z Jolantą Wadowską-Król rozmawia Lucyna Sadzikowska
}

Z Panią Doktor Jolantą Wadowską-Król ${ }^{1}$ spotkałam się w Jej domu w Katowicach-Ligocie 6 października 2020 roku. Pretekstem do rozmowy

${ }^{1}$ Jolanta Danuta Wadowska-Król urodziła się 27 czerwca 1939 r. w Katowicach. Jej ojcem był Piotr Wadowski, matką - Stanisława z Chwistów, a mężem - Zbigniew Józef Król (ur. 23 września 1936 r. w Łagiewnikach, zm. 17 września 2020 r. w Katowicach; adiunkt w Instytucie Chorób Wewnętrznych - Klinika Nefrologii). Studia w Śląskiej Akademii Medycznej w Katowicach ukończyła w 1964 r. Pracowała w Wojewódzkim Szpitalu Zespolonym w Katowicach, w Poradni Dziecięcej w Dąbrówce Małej. W 1984 r. została odznaczona medalem 40-lecia PRL. W 2005 r. Zarząd Regionu Śląsko-Dąbrowskiego NSZZ „Solidarność” przyznał Jolancie Wadowskiej-Król Złoty Medal „Solidarności”. W 2013 r. podczas uroczystości wręczenia Śląskiej Nagrody Obywatelskiej otrzymała Nagrodę Specjalną. W marcu 2015 r. została wyróżniona przez Rzecznik Praw Obywatelskich odznaką honorową „Za zasługi dla Ochrony Praw Człowieka”. W 2018 r. została laureatką Nagrody im. Wojciecha Korfantego. W listopadzie tego samego roku w Katowicach przy ul. Gliwickiej odsłonięto mural Andrzeja Wieteszki poświęcony lekarce.

Podczas kwerendy przeprowadzonej w Oddziałowym Archiwum IPN-KŚZpNP w Katowicach znaleziono Jej akta paszportowe, metryczki i książeczki paszportowe. Dokumentacja zawierała m.in. podanie z 7 marca 1989 r. o wyjazd do Austrii przez Czechosłowację w dniach 27 kwietnia-7 maja 1989 r. w celu turystycznym z biurem Juventur (w dokumencie tym Jolanta Wadowska-Król oświadczyła, że posiada środki dewizowe na czas pobytu), podanie o wyjazd do 
z Panią Doktor, lekarzem pediatrą zwaną Matką Boską szopienicką ${ }^{2}$, Honorową Obywatelką Katowic ${ }^{3}$, na temat Jej pracy z szopienickimi, chorymi na ołowicę dziećmi oraz na ich rzecz było podjęcie 29 września 2020 roku przez Senat Uniwersytetu Śląskiego w Katowicach uchwały o wszczęciu postępowania o nadanie Pani Doktor tytułu Doktora Honoris Causa US ${ }^{4}$. Wywiad trwał około dwóch godzin, podczas których moja rozmówczyni wielokrotnie podkreślała, że w Jej ocenie niczego wielkiego nie zrobiła, zaś informacja o tym, że na Uniwersytecie Śląskim rozpoczęła się procedura uhonorowania Jej najwyższą przyznawaną przez uczelnię godnością akademicką, zestresowała Ją.

Jolanta Wadowska-Król: ... wie Pani, pracowałam normalnie, po ludzku.

Lucyna Sadzikowska: „Po ludzku” to kwintesencja Pani pracy i - jak sądzę motyw, którym kierowali się członkowie wspólnoty Uniwersytetu Śląskiego, by wyróżnić Panią tytułem Doktora Honoris Causa. Uczelnia dba, by osoby nominowane do tej godności legitymowały się wybitnymi osiągnięciami oraz wyróżniały się niekwestionowanym autorytetem moralnym i etycznym. Ten szczególny tytuł otrzymują ci, których cechuje niezłomna chęć poszukiwania prawdy, którzy są uczciwi i pracowici, działają pro publico bono, którzy wy-

Turcji w 1985 r., a w 1980 r. do Włoch i Jugosławii. Prosiła również o wyrażenie zgody na wyjazd do Holandii, Turcji i Grecji. Podane tu informacje opracowano na podstawie dokumentacji udostępnionej podczas kwerendy przeprowadzonej 16 października 2020 r. - przejrzano i zapoznano się z oryginałami akt o sygn. IPN Ka 620/12774 oraz wydrukami zapisów ewidencyjnych z bazy komputerowej Cyfrowe Archiwum dotyczącymi Jolanty Wadowskiej-Król.

${ }_{2}$ Matka Boska szopienicka. Reż. M. Król. Scen. M. Król, K. Skibińska. Polska 2013. Dostępne w Internecie: https://www.youtube.com/watch?v=FTc2RUNGsi0 [data dostępu: 4.10.2020]. Film nakręcony na konkurs „Szukamy bohaterów”.

${ }^{3}$ We wrześniu 2017 r. Jolanta Wadowska-Król otrzymała tytuł Honorowego Obywatela Miasta Katowice. Zob. A. Malinowska: Doktor Jolanta Wadowska-Król Honorowa Obywatelka Katowic. Uratowała setki dzieci. „Gazeta Wyborcza” z 11 września 2017 r. [dodatek: „Katowice”]. Dostępne w Internecie: https://katowice.wyborcza.pl/katowice/7,35063,22354742,doktor-jolantawadowska-krol-honorowa-obywatelka-katowic.html [data dostępu: 5.10.2020].

${ }^{4}$ Uchwała nr 39 Senatu Uniwersytetu Śląskiego w Katowicach z dnia 29 września 2020 r. w sprawie wszczęcia procedury nadania tytułu doktora honoris causa Uniwersytetu Śląskiego w Katowicach Pani Jolancie Wadowskiej-Król. Dostępne w Internecie: http://bip.us.edu.pl/ uchwala-nr-392020 [data dostępu: 19.10.2020]. 
znawanymi zasadami oraz postawą etyczną pokazują, że w dzisiejszym świecie wartości wciąż mają fundamentalne znaczenie. Zapewne recenzenci ${ }^{5}$ powołani w przewodzie o nadanie tego tytułu uwypuklą i docenią wszystkie aspekty pracy zawodowej oraz postawy życiowej Pani Doktor.

J.W.K.: Nadal nie jestem pewna, czy na to wszystko zasłużyłam. Nie, nie zasłużyłam. Po prostu pracowałam. Przede wszystkim myślę, że o ołowicy powinna powstać książka.

L.S.: Pani Doktor, zacznijmy od początku. Jak to się zaczęło?

J.W.K.: 4 września 1974 roku przyjechała do mnie Profesor Bożena Hager-Małecka ${ }^{6}$ i powiedziała, że ma dziecko $\mathrm{z}$ mojego regionu chore na ołowicę. Przeraziłam się, wiedziałam, że działa tam huta ołowiu. Pani Profesor stwierdziła, że trzeba zbadać kilkoro dzieci sąsiadów i sprawdzić, czy też mają ołowicę, czy występują u nich podwyższone poziomy ołowiu, co się z nimi i z ich zdrowiem dzieje. W pierwszej kolejności zbadałam chyba dziesięcioro dzieci. Skierowałam je do laboratorium od razu, następnego dnia. Dostałam wyniki i ogarnęło mnie przerażenie. Przeraziłam się ze względu na zdrowie tych dzieci. Nie myślałam już o tym, że Pani Profesor prosiła o kilka badań, tylko zaczęłam zlecać ich wykonanie na masową skalę. Pojechałam do swojego przełożonego dr. Urbana i zapytałam, czy mogę przeprowadzić taką liczbę badań. Usłyszałam:

${ }^{5} 27$ października 2020 r. podczas posiedzenia Senatu Uniwersytetu Śląskiego podjęto uchwałę, by recenzentami w postępowaniu o nadanie tytułu Doktora Honoris Causa UŚ Pani Jolancie Wadowskiej-Król byli: prof. dr hab. n. med. Grzegorz Opala, prof. dr hab. n. med. Mieczysława Czerwionka-Szaflarska, prof. dr hab. Michał Daszykowski oraz prof. dr hab. n. med. Tomasz Szczepański.

${ }^{6}$ Prof. dr hab. n. med. Bożena Hager-Małecka, Doktor Honoris Causa Śląskiej Akademii Medycznej, twórczyni śląskiej szkoły pediatrycznej, naukowiec, lekarka i społecznik. Od 1949 r. była związana ze śląską pediatrią; najbliższa współpracownica, a później godna następczyni organizatora Katedry i Kliniki Pediatrii w Zabrzu, prof. dr. hab. Artura Chwalibogowskiego. Zob. Bożena Hager-Małecka: naukowiec, pediatra, społecznik. Oprac. zespół pod red. K. Karczewskiej, M. Łukasik, E. Kyas. Katowice 2001. Dostępne w Internecie: https://www.sbc.org.pl/dlibra/ publication/3342/edition/3101/content [data dostępu: 10.10.2020].

${ }^{7}$ Chodzi o Hutę Metali Nieżelaznych w Katowicach-Szopienicach. 
„jak chcesz, to rób, mnie w to nie mieszaj”. Pojechałam do laboratorium, nikt się nie sprzeciwiał. Wszyscy byli za, cała tzw. służba zdrowia zareagowała jednogłośnie: „chcesz, to rób”. Skoro nie usłyszałam słów sprzeciwu od przełożonego, pracownicy laboratorium też nie zaprotestowali, sygnalizując, że zrobią badania, nie dociekając powodów, zaczęłam masowo diagnozować. Dziennie do różnych laboratoriów kierowałam 50-70 dzieci. Rozmawiając z kierownikami tych jednostek, uzgadniałam, ile dodatkowo mogłyby przyjąć zleceń, co dawało mi możliwości badania 50-70 dzieci dziennie. Wyniki były przerażające. W pierwszym sprawozdaniu dla Profesor Bożeny Hager-Małeckiej napisałam, że wyniki są bardzo złe i że należy jak najszybciej skierować te wszystkie dzieci do szpitala. Błyskawicznie zaczęłam wysyłać najmłodszych chorych do okolicznych lecznic: do kliniki w Zabrzu, do szpitala w Sosnowcu, do Ligoty, do oddziału dziecięcego w Załężu, do tzw. zameczku w Ligocie. Oczywiście szpitale zatkały się, były przepełnione. Zrodziło się pytanie: co robić? Przewodniczącą Wojewódzkiego Ośrodka Matki i Dziecka była pani dr Zofia Kajzerowa, która zarządzała sanatoriami w województwie. Porozmawiałam z nią i wyraziła zgodę, by kierować te dzieci do Istebnej. Pojechały tam dwa lub trzy autobusy. Pani Wiesia Wilczek, moja prawa ręka, wypisała razem ze mną skierowania i wnioski do Istebnej. Bazowałyśmy na danych, które posiadałyśmy: informacje o wzroście i wadze dziecka czerpałyśmy z kartoteki, wpisywałam, że znam te wszystkie dzieci. W jednym dniu wypisywałyśmy około 60 wniosków, bo tyle dzieci mieścił autokar. Rozesłałyśmy je do wszystkich możliwych sanatoriów w okolicy. W pierwszej kolejności Istebna, potem Rabka, następnie Bucze i Jaworze. Kierowałyśmy dzieci, dokąd tylko się dało - na terenie naszego województwa i poza nim. Najprawdopodobniej najlepiej wyszły na tym te, które pojechały do sanatoriów, bo ołów z organizmów był wydalany bardzo powoli. W dobrych warunkach, na świeżym powietrzu, niezgorzej odżywione dziecko miało szansę, by wydalić ołów, był to jednak systematyczny i powolny proces. Istniało prawdopodobieństwo, że dziecko „wypłucze się” samo. I tak w większości się stało. Od początku zdawałam sobie jednak sprawę, że moje działania nie są na rękę władzy. Profesor Bożena Hager-Małecka ostrzegała: „uważaj, bo nas mogą zamknąć albo przerwać te badania, i to będzie najgorsze, bo wtedy dzieciom się nie pomoże". Uznałam, że jeśli miałoby się tak stać, to trzeba przyspieszyć diagnostykę. Zaczęłam indywidualnie rozmawiać z każdym z rodziców. Mówiłam, 
że nie należy się buntować, nikogo informować, trzeba badać dziecko i - jeśli zajdzie taka potrzeba - leczyć je. Prosiłam, żeby nie robić szumu i zamieszania, wówczas inni nie zostaliby zbadani. Rodzice bardzo rozumnie do tego podchodzili. Nie było buntu, nikt nic nie mówił. Dzieci, które otrzymywały wezwania, w 100\% stawiały się na badania. Dyscyplina wśród ludzi była niesamowita. Nikt nie zgłosił sprzeciwu. To był pierwszy pozytywny znak, że sprawa „idzie” do przodu. Ponieważ rozkręciłam to bardzo szybko, władze nie mogły już niczego zrobić. Nie mogły mnie uciszyć, bo wiedziały, że wiele dzieci już zostało zbadanych, ani przerwać tych badań. Po pewnym czasie, po zbadaniu dużej liczby dzieci i rozesłaniu ich do sanatoriów, a kierowałam je, dokąd tylko mogłam, zdecydowano o utworzeniu jednego laboratorium, które miało za zadanie opanować wszystkie nasze działania. Pan dr Grzybowski, dyrektor wojewódzkiego sanepidu, zatrudnił laborantki, które specjalizowały się w tej dziedzinie, i stworzył laboratorium. Kupił spektrofotometr, który bada poziom ołowiu, i usystematyzował te działania. Ale to już był rok 1976, koniec roku 1975. Dzieci z najbliższego otoczenia huty zostały już wówczas rozesłane do sanatoriów. Po stworzeniu wspomnianego laboratorium laborantki jeździły do szkół i przedszkoli, pobierały dzieciom krew i badały. Po otrzymaniu wyników działałam dalej. Jeśli dziecko miało złe wyniki, to podejmowałam konieczne kroki.

L.S.: W tle tych wydarzeń toczyła się sprawa Pani doktoratu, prawda?

J.W.K.: W ogóle o doktoracie nie myślałam. Po prostu byłam w amoku, wiedziałam, że mam pracować, między innymi wypisując wyniki. Decydowałam, które dziecko dokąd wyjedzie, organizowałam ich leczenie. Planowałam, co mam kolejnego dnia załatwić, czyli ile dzieci i do którego sanatorium wysłać. O żadnym doktoracie nie myślałam, zresztą mowy o tym nie było. Ważna była praca i ratowanie dzieci. Wiedziałam, że nie odbiorą mi dyplomu lekarskiego. Jeśli mnie aresztują, myślałam, trudno. Sporo ludzi siedziało, to i ja mogłam trafić do więzienia, choć nic złego nie zrobiłam. W każdym razie, kiedy sanepid opanował sytuację i atmosfera uspokoiła się, zeszłam w walce $z$ ołowicą na drugi plan, odgrywałam w tej sprawie mniejszą rolę. Połowa dzielnicy została wywieziona, bo trzeba dodać, że dzieci przebywały w sanatoriach po kilka miesięcy, nawet pół roku lub dłużej, do momentu, kiedy rodzice nie otrzymali 
nowych mieszkań. O te lokale też z hutą walczyłam. Michał Jędryka napisał, że siedziałam u dyrektora huty $\mathrm{w}$ poczekalni ${ }^{8}$. Nie, nie jest to prawda. To mi się nie zdarzało. Nie poszłam tam jako interesant, poszłam z pozycji siły. Wszędzie chodziłam z przekonaniem o słuszności sprawy, w ogóle nie czułam strachu. Nie bałam się słów, nie bałam się działania, niczego się nie bałam. Szłam przed siebie $\mathrm{z}$ poczuciem pewności, co i jak mam zrobić. W związku z tym nigdy u dyrektora w poczekalni nie siedziałam. Jeżeli mnie zaprosił, bo chciał porozmawiać, to on musiał czekać.

L.S.: A nie na odwrót...

J.W.K.: Tak, bo miałam ogromne pretensje do tej huty. Potworny żal, że mają filtry, które otwierali w nocy. Nie można było przez to oddychać. Wiedzieli, że wśród dzieci panuje ołowica, że nie wszystkie zostały przeniesione $\mathrm{z}$ tego niebezpiecznego terenu. Pytałam ludzi, którzy pracowali w hucie, między innymi rodziców dzieci chorych, dlaczego otwierają filtry. Przekonywałam: przecież są wyniki z sanepidu, z których wynika, że w nocy emitujecie mnóstwo ołowiu. Słyszałam: ,ja, doktórko, jakby my tak nie robili, to nic my by zarobili”. Filtry hamowały produkcję, w ogóle się nie paliło, więc w nocy je otwierano. Z tego powodu też się denerwowałam na tę hutę. Na początku robiłam partyzantkę, ale istniała niepisana zasada: cisza, spokój, dzieci wysyłamy do sanatorium. Mechanizm działania można określić jako zorganizowany. I wtedy, po powstaniu laboratorium w sanepidzie, Profesor Bożena Hager-Małecka wezwała mnie i zaproponowała, bym napisała $\mathrm{z}$ tego doktorat. To było łatwe, że tak to ujmę. Miałam statystyki, materiał badawczy, ogromną rzeszę chorych dzieci, wybrałam grupę kontrolną z daleka - spod Mysłowic. Doktorat napisałam szybko i zawiozłam do Profesor Hager-Małeckiej, która tekst przeczytała, zaakceptowała, ale wskazała mnóstwo fragmentów, które należało wykreślić, między innymi wyrysowane przeze mnie słupki oparte na danych statystycznych. Niewiele $\mathrm{z}$ tego doktoratu zostało, to, co najważniejsze, trzeba było wyrzucić.

${ }^{8}$ „W sekretariacie natknęliśmy się jeszcze na doktor Król. Czekała na tego samego dyrektora. Przywitała się z matką" (M. Jędryka: Ołowiane dzieci. Zapomniana epidemia. Wydawnictwo Krytyki Politycznej, Warszawa 2020, s. 147). 
Przede wszystkim w tytule pracy nie mogło znaleźć się słowo „zatrucie”, które zostało tak zakamuflowane, że nie byłam w stanie tego tytułu powtórzyć. Coś okropnego. Kiedy wykreślono, jaki był poziom ołowiu u dzieci chorych, to treść dysertacji traciła sens. Normy wynosiły wtedy 30-35 mikrogramów na decylitr, współcześnie norma to 5 . Wtedy 35! To była przyjęta norma! Ale jeśli nawet tego nie mogłam w tekście podać, to sama praca traciła sens. Pozostał jeden wykres, na podstawie którego można się było domyślić, że chore dzieci to jeden słupek, a zdrowe dzieci to drugi słupek, ale nie mogłam pozostawić żadnych liczb. Kompletnie bez sensu. Nie wiem, jak to się stało i w jakiej postaci tekst doktoratu dotarł do rektora. Szefem decydującym o życiu lub śmierci ludzi na Śląsku był Grudzień1 ${ }^{10}$, człowiek dosyć ograniczony, najprawdopodobniej niewykształcony, prosty. Gierek ${ }^{11}$ był bardziej światły. Dowiedziałam się, że

${ }^{9}$ Do wywiadu dołączono fotografię karty tytułowej rozprawy doktorskiej, na której na maszynie i ręcznie napisano propozycje trzech tematów: „Wpływ [później, po rozmowie z prof. Jerzym Żmudzińskim, dopisane ręcznie długopisem przez Jolantę Wadowską-Król: mikro - L.S.] środowiska wielkoprzemysłowego na stan zdrowia dzieci zamieszkałych w sąsiedztwie źródła emisji pyłów metalicznych”; następnie odręcznie długopisem: „Intoksykacja [nad wyrazem napisane: zatrucie - L.S.] ołowiem u dzieci zamieszkałych w sąsiedztwie źródła emisji [przekreślone: pyłów - L.S.]”; „Ocena stanu zagrożenia ołowicą dzieci mieszkających w pobliżu huty ołowiu”. Autorką wszelkich odręcznych dopisków jest Jolanta Wadowska-Król zainspirowana sugestiami prof. J. Żmudzińskiego. We wniosku Jolanty Wadowskiej-Król do dziekana Wydziału Lekarskiego ŚAM z 1 marca 1977 r. zaproponowany tytuł brzmi: „Wpływ mikrośrodowiska wielkoprzemysłowego na stan zdrowia dzieci zamieszkałych w sąsiedztwie źródła emisji pyłów metalicznych" (kserokopia pisma przekazana UŚ przez SUM 4 grudnia 2020 r.).

${ }_{10}$ Zdzisław Grudzień (ur. 6 października 1924 r. w Escaudain we Francji, zm. 30 stycznia 1982 r. w Głębokim) - polski polityk, działacz partyjny, komunista, górnik, absolwent AGH. W latach 1965-1982 poseł na Sejm PRL IV-VIII kadencji. Po wprowadzeniu stanu wojennego internowany m.in. wraz z Edwardem Gierkiem. Zob. B. Snoch: Górnośląski leksykon biograficzny. Suplement do wydania drugiego. Muzeum Śląskie, Katowice 2006, s. 46.

${ }^{11}$ Edward Gierek (ur. 6 stycznia 1913 r. w Porąbce, zm. 29 lipca 2001 r. w Cieszynie) - polski polityk, działacz komunistyczny, w latach 1970-1980 I sekretarz KC PZPR, poseł na Sejm PRL I-VIII kadencji. Członek Rady Państwa (1976-1980), w latach 1971-1981 członek prezydium Ogólnopolskiego Komitetu Frontu Jedności Narodu. Budowniczy Polski Ludowej. Zob. J. Rolicki: Edward Gierek. Życie i narodziny legendy. Iskry, Warszawa 2002; A. Paczkowski: Pół wieku dziejów Polski. Wydawnictwo Naukowe PWN, Warszawa 2005; J. Eisler: Siedmiu wspaniałych. Poczet pierwszych sekretarzy KC PZPR. Wydawnictwo Czerwone i Czarne, Warszawa 2014. 


\section{JOLANTA WADOWSKA KROL}

Rozprawa na stopień doktora nauk medycznych
pt:

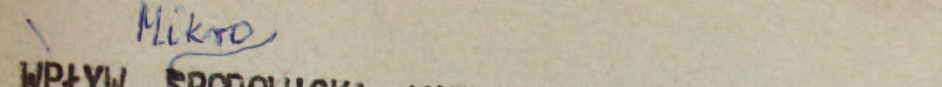
WPLYW SROOOWISKA WIELKOPRZEMYSLOWEGO NA STAN ZDROWIA DZIECI ZAMIESZKALYCH W SASIEDZTWIE ZRODLA EMISJI PYLON METALICZNYCH

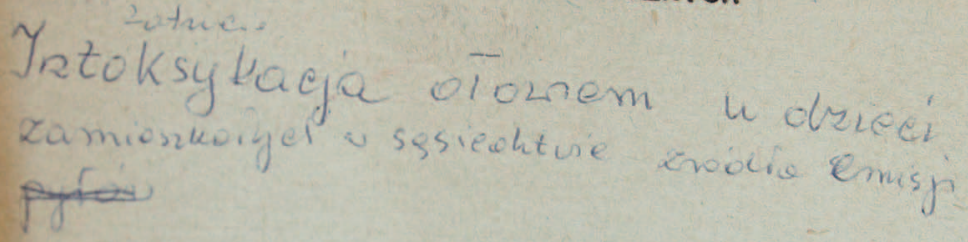


kiedy badałam ołowicę, Grudniowi urodziło się dziecko. Nie chciał go karmić mlekiem pochodzącym stąd, dlatego jeździł do Miasteczka Śląskiego po mleko od tamtejszych krów. Tymczasem w Miasteczku Śląskim było drugie źródło ołowicy, ponieważ przeniesiono tam wszelkie działania związane z przetapianiem akumulatorów. Rektor Jan Jonek ${ }^{12}$ był - nazwijmy go tak - przyjacielem Grudnia. I stało się, jak się stało. W zasadzie nie dziwię się, że recenzje były negatywne, skoro tyle rzeczy wykreślono.

\section{L.S.: Czy posiada Pani egzemplarz tej rozprawy?}

J.W.K.: Tylko tę ostateczną wersję, osobno powykreślane notatki, ale to się już do niczego nie nadaje, nikt $\mathrm{z}$ tego nic nie wie. Pokazywałam to moim dzieciom, tego już nie da się wykorzystać. Po odwilży ktoś mnie wezwał w sprawie doktoratu, zajrzałam do tych notatek i doszłam do wniosku, że musiałabym wszystko napisać od początku. Nie miało to sensu. Ważne informacje zostały wykreślone w pierwszej kolejności.

${ }^{12}$ Prof. nadzw. dr hab. n. med. Józef Jan Jonek (ur. 8 marca 1928 r. w Kolonowskiem Śląskim w powiecie strzeleckim, zm. 1 września 2000 r. w Bonn) - w latach 1950-1955 odbył studia na Wydziale Lekarskim ŚAM. Od 1952 r. pracował najpierw jako asystent bez dyplomu, następnie jako starszy asystent w Katedrze Histologii i Embriologii ŚAM. W 1957 r. uzyskał stopień kandydata nauk medycznych. W 1962 r. po przeprowadzeniu przewodu habilitacyjnego został powołany na stanowisko docenta. W $1971 \mathrm{r}$. otrzymał tytuł naukowy profesora nadzwyczajnego. Od 1964 r. był kierownikiem Zakładu Histologii i Embriologii, a od 1971 r. - dyrektorem Instytutu Biologiczno-Morfologicznego ŚAM. Urząd rektora ŚAM sprawował w latach 19711980. Zainteresowania naukowo-badawcze Profesora Jonka obejmowały m.in. wpływ promieniowania jonizującego, wibracji i hałasu oraz różnych czynników środowiskowych, a w szczególności przemysłowych substancji toksycznych, na ustroje żywe i człowieka. Badał również oddziaływanie hormonów na metabolizm komórek i tkanek. Autor i współautor 240 publikacji, w tym 86 ogłoszonych w specjalistycznych czasopismach zagranicznych. Promotor 27 przewodów doktorskich, opiekun 3 habilitacji, recenzował 46 prac doktorskich i 26 habilitacyjnych. Był członkiem wielu towarzystw naukowych, m.in.: Polskiego Towarzystwa Anatomicznego, Polskiego Towarzystwa Histo- i Cytochemików, Polskiego Towarzystwa Endokrynologicznego, Polskiego Towarzystwa Lekarskiego, Austriackiego Towarzystwa Mikroskopii Elektronowej. Odznaczony m.in.: Orderem Sztandaru Pracy II kl., Krzyżem Kawalerskim Orderu Odrodzenia Polski i nagrodą państwową. Zwolniony z pracy w ŚAM z dn. 31 lipca 1981 r. Zob. http://70lat. sum.edu.pl/index.php/rektorzy-sum/ [data dostępu: 12.10.2020]. 
L.S.: Ale rozpoczęto procedurę mającą na celu nadanie Pani stopnia doktora?

J.W.K.: Tak ${ }^{13}$, podczas wszczęcia przewodu doktorskiego powiedziałam swoimi słowami wszystko to, co napisałam, całą prawdę. Wszystkim bardzo podobała się moja wypowiedź. Ktoś - nie pamiętam kto - powiedział mi, że moje badania i wyniki nadają się na habilitację. Wszyscy byli zachwyceni. A po wszczęciu przewodu wszystko się skończyło ${ }^{14}$.

${ }^{13} \mathrm{~W}$ piśmie z 4 grudnia 2020 r. (znak: PCN-CRN/640-1-29/214/2/20) rektor Śląskiego Uniwersytetu Medycznego prof. dr hab. n. med. Tomasz Szczepański poinformował rektora Uniwersytetu Śląskiego prof. dr. hab. Ryszarda Koziołka, że w trakcie działań archiwizacyjnych odnaleziono dokumenty dotyczące przewodu doktorskiego Pani Jolanty Wadowskiej-Król: 1) wniosek Pani Jolanty Wadowskiej-Król z 1 marca 1977 r. w sprawie wyrażenia zgody na wszczęcie przewodu doktorskiego, 2) życiorys Pani Jolanty Wadowskiej-Król, 3) artykuł Pani Jolanty Wadowskiej-Król „Czynniki pokarmowe a toksyczność metali ciężkich”, 4) pismo prof. dr hab. Bożeny Hager-Małeckiej z 4 marca 1977 r., 5) pismo Pani Jolanty Wadowskiej-Król z 15 kwietnia 1977 r., 6) wyciąg z protokołu nr 18 z posiedzenia Rady Instytutu Pediatrii, które odbyło się 20 maja 1977 r., 7) artykuł współautorstwa Pani Jolanty Wadowskiej-Król pt. „Przewlekła ołowica u rodzeństwa z mukopolisacharydozą Sanfilippo”, 8) spis prac Pani Jolanty Wadowskiej-Król, 9) wstępna ocena pracy doktorskiej (brak autora), oznaczona „I rec.”, 10) wstępna ocena pracy doktorskiej (brak autora), oznaczona „II rec.”, 11) wstępna ocena pracy doktorskiej (brak autora), oznaczona „III rec.”, 12) odręczna notatka (nazwisko autora nieczytelne) z 5 maja 1982 r., 13) pismo adresowane do kierownika dziekanatu z 5 lipca 1983 r.

${ }^{14} \mathrm{Z}$ kwerendy archiwizacyjnej SUM wynika następująca chronologia zdarzeń: 1 marca 1977 r. Jolanta Wadowska-Król skierowała do ówczesnego dziekana Wydziału Lekarskiego ŚAM prośbę o wyrażenie zgody na wszczęcie przewodu doktorskiego, wraz z życiorysem. 4 marca 1977 r. prof. dr hab. Bożena Hager-Małecka złożyła ówczesnemu rektorowi ŚAM pismo (czytamy w nim: „[...] w ślad za przeprowadzoną rozmową przedkładam JM Rektorowi materiały dotyczące wszczęcia przewodu doktorskiego lekarza Jolanty Wadowskiej-Król”), na którym z datą 2 września 1977 r. rektor ŚAM prof. dr hab. n. med. Jan Jonek odręcznie napisał: „Brak piśmiennictwa wstrzymać”. 15 kwietnia 1977 r. Jolanta Wadowska-Król zwróciła się z prośbą do prof. dr. hab. n. med. Mieczysława Krauze, dyrektora Instytutu Pediatrii, o wyrażenie zgody na otwarcie przewodu doktorskiego, dodając, że jest współautorką trzech prac. Na piśmie adresat odnotował 21 kwietnia 1977 r., że popiera wniosek. W wyciągu z protokołu nr $18 \mathrm{z}$ posiedzenia Rady Instytutu Pediatrii z 20 maja 1977 r., który podpisali sekretarz Rady Instytutu Pediatrii dr n. med. Eugeniusz Pyda oraz dyrektor Instytutu Pediatrii Profesor Mieczysław Krauze, stwierdzono, że prof. dr hab. Bożena Hager-Małecka, prorektor ds. klinicznych, wystąpiła z wnioskiem o zatwierdzenie tematu pracy doktorskiej lek. med. Jolanty Wadowskiej-Król i jednocześnie wyjaśniła, że zarówno materiał, jak i wyniki pracy w dużej mierze objęte są tajemnicą państwową 
L.S.: Kto recenzował Pani dysertację doktorską?

J.W.K.: Recenzje były anonimowe. Miałam dwie recenzje bez podpisów. Posiadam tylko dokument wzywający mnie na posiedzenie, podczas którego podejmowano decyzję o otwarciu mojego przewodu doktorskiego, i podanie o wszczęcie postępowania, w którym napisałam, że typ pracy wymaga procedury utajnienia, co zostało skonsultowane z ówczesnym prorektorem ds. nauki doc. dr. hab. Markiem Machalskim ${ }^{15}$. Chciałabym podkreślić, że rzetelnie pracowałam, miałam ogromną satysfakcję ze swojej pracy. Zapomniałam o tym doktoracie.

L.S.: Na pewno było Pani przykro.

J.W.K.: Tak, to było przykre. Kiedy odmówiono mi tego doktoratu, po prostu się odcięłam. Przyjmowałam wyniki wyłącznie z tego konkretnego sanepidu i działałam, jak było trzeba. Wyprowadzałam ludzi z choroby, podczas gdy wyburzano familoki wokół huty. Załatwiałam dla dzieci z Szopienic mleko w proszku na kartki. Cóż lepszego mogło mnie spotkać... Miałam satysfakcję z wykonywanej pracy, a to, że na nagrobku nie napiszą mi doktor nauk - to nie było ważne. I choć czułam się usatysfakcjonowana i spełniona, to jednak wewnątrz targał mną smutek. W wolnych chwilach zaczęłam więc haftować.

L.S.: Zauważyłam, że na ścianach wiszą wyhaftowane portrety.

J.W.K.: Wszystkie są wykonane haftem krzyżykowym. Po sprawie z doktoratem szukałam czegoś, co mnie uspokoi. Haftowanie mnie wycisza. Teraz, po śmierci męża, wróciłam do tego. To pomaga złapać równowagę psychiczną.

i nie mogą być publikowane oraz szerzej omawiane na posiedzeniu Rady Instytutu. W związku z tym Rada Instytutu jednogłośnie zatwierdziła temat bez bliższego jego omówienia. Warto dodać, że na drugiej wstępnej ocenie pracy doktorskiej widnieje data 10 października $1979 \mathrm{r}$. Druga i trzecia wstępna recenzja opatrzone zostały klauzulą: poufne.

${ }_{15}$ Pierwszym dziekanem drugiego Wydziału Lekarskiego ŚAM w Katowicach, utworzonego w wyniku podziału ówczesnego Wydziału Lekarskiego z Oddziałem Stomatologicznym, został w czerwcu 1975 r. doc. dr hab. Marek Machalski. 
L.S.: A jak to było z Matką Boską szopienicką?

J.W.K.: Następczyni dr. Grzybowskiego, dyrektor wojewódzkiego sanepidu dr Karczmarzowa powiedziała: „Znalazła się jakaś Matka Boska szopienicka i miesza ludziom w głowach”. W jej ocenie podburzałam ludzi.

L.S.: Skąd wynikał Pani brak strachu? Wychowanie, wartości wpojone przez rodzinę, przysięga Hipokratesa?

J.W.K.: Czy ja wiem... Moi rodzice byli wielkimi patriotami. Ojciec w sumie przypłacił to życiem. Poszedł we wrześniu 1939 roku do wojska, miał zbiórkę w Krakowie. Wojsko zdążyło wymaszerować w kierunku Rumunii, on ich gonił, a inni zostawali. Moja mama, kiedy żegnała się z ojcem, powiedziała mu, trzymając sześciotygodniowe dziecko na rękach: „idź i walcz”. Nienormalne. Można być patriotą, ale bez przesady. Ojciec walczył i przeszedł cały szlak wojenny z Armią Andersa. Zginął w marcu 1945 roku, u nas wojna skończyła się już w styczniu. Spoczywa na bolońskim cmentarzu. Przeżył Monte Cassino i walki pod Tobrukiem, a zginął w ostatnich dniach wojny. Z czego wynika moja postawa? Nie wiem. Wiedziałam, że tym biednym ludziom nikt nie pomoże. Byłam lekarzem rejonowym, pediatrą i wiedziałam, że jeśli ja im nie pomogę, to nikt tego nie zrobi, bo nikt nie wykazywał chęci pomocy. Być może wynika to $\mathrm{z}$ faktu, że przeżyłam ciężkie chwile w dzieciństwie i młodości. Wychowywałam się bez ojca, który przed wojną był kierownikiem polskiej szkoły w Bielszowicach. Mama została sama. Kiedy miałam rok, uległa wypadkowi - w wyniku porażenia piorunem częściowo straciła wzrok. Zaczęła dobrze widzieć dopiero po przeszczepie soczewek, wtedy nawet haftowała. Wychowywałam się w zasadzie sama, więc życie nie było łatwe. Mama, która była nauczycielką, po wypadku nie mogła pracować w zawodzie. Potem zatrudniono ją w przedszkolu. Polegałam na sobie, wiele spraw było na mojej głowie. Sześć razy zmieniałam szkołę. $\mathrm{Z}$ powodu trudnej sytuacji $\mathrm{w}$ domu mama zamieszkała u jednej z kilku sióstr, a ja u drugiej. Byłyśmy osobno. Zmieniałam szkoły, zmieniałam miejsca pobytu. To też jakoś na mnie wpłynęło, ukształtowało mój charakter. Wiedziałam, że muszę się usamodzielnić, bo mogę liczyć tylko na siebie. 
Między innymi dlatego ciągle towarzyszyła mi myśl, że jeśli nie pomogę tym szopienickim dzieciom, to nikt im nie pomoże. Czułam, że jestem władna, by kierować te dzieci do lepszych miejsc, do leczenia, chronić je. Przy tym - jeszcze raz podkreślę - nikt ze służby zdrowia nie przeszkadzał mi. Wszyscy wychodzili z założenia: chcesz, to rób, tylko daj nam spokój. Postawa tych ludzi była bierna, pasywna, ale nieszkodliwa. Robiłam, co chciałam. Kiedy na przykład brakowało aparatów do przetaczania jednorazowego, bo w szpitalu dzieci leczyli chelatonem, to załatwiałam gdzieś ten sprzęt, dyrektor dzwonił i wydawano mi go. Robiłam wszystko, co było możliwe w tamtych czasach, by ratować te dzieci. I one przeżyły, mają teraz po pięćdziesiąt-sześćdziesiąt lat. Niektórzy kontaktują się ze mną. Ostatnio była akcja na Facebooku i dzieci - ciągle ich tak nazywam - ci ludzie, którzy mnie znają, przesłali mi wiadomości.

L.S.: To musi być spora grupa.

J.W.K.: Duża grupa, choć te bardzo chore dzieci zmagają się z problemami w życiu. Bardzo wiele spośród nich już nie żyje.

L.S.: Znikająca klasa ${ }^{16}$, by użyć tytułu jednego z rozdziałów w książce Michała Jędryki.

J.W.K.: Szkoła, do której chodził Michał Jędryka, była położona nieco dalej od zakładu hutniczego. Najciężej chorzy mieszkali bardzo blisko huty, komin był w zasadzie po drugiej stronie ulicy. Tam teraz jest wielki park, nawet basen wybudowano na miejscu tych domów.

L.S.: W tej ziemi nadal jest ołów?

J.W.K.: Tak, jest. Stwierdzam to na podstawie danych zebranych przez sanepid, do których miałam wgląd. Do pewnego momentu pozwalano mi zaglądać do wyników badań sanepidu, ale któregoś dnia to się skończyło. Przyszłam jak

${ }^{16}$ Znikająca klasa to tytuł czwartego rozdziału książki Michała Jędryki Ołowiane dzieci... (s. 33-42). 
zawsze i inż. Zimander, który zajmował się wynikami dotyczącymi poziomu ołowiu w powietrzu i ziemi, powiedział, że dyrektorka zakazała mu podawać informacje na ten temat. W taki sposób odcięto mi dostęp do danych.

L.S.: Pewnie za dużo Pani wiedziała.

J.W.K.: Powiedziano mi, że ziemia, na której stoją familoki, to jest słaba ruda. Przekopali tę ziemię, posadzili drzewa, ale ołów w tej glebie pozostał. Na pewno wniknął bardzo głęboko.

L.S.: Mam nadzieję, że do numeru czasopisma „Narracje o Zagładzie”, poświęconego zagadnieniu ołowiu, artykuł napiszą geolodzy z Uniwersytetu Śląskiego, którzy zaprezentują stan badań w tym zakresie.

J.W.K.: Na terenie, na którym odnotowano największe skażenie ziemi, powstał plac zabaw: rosną drzewa, jest park, są ławeczki, ale nigdy nie widziałam tam bawiących się dzieci. To duża powierzchnia, było tam sporo domów, gęsta zabudowa, budynki były wręcz ściśnięte jeden koło drugiego. Brakowało tam wielkich podwórek, nie było betonu, tylko klepisko - nic zielonego tam nie rosło. Zero trawy, psów, ptaków.

L.S.: A kiedy usłyszała Pani po raz pierwszy o ołowicy? Na studiach?

J.W.K.: O ołowicy nie mówiło się w ogóle, co najwyżej w kontekście choroby zawodowej. To był dla mnie szok. Nie było literatury na ten temat. Kiedy Profesor Bożena Hager-Małecka przyjechała, żeby mnie zawiadomić, że jest pierwszy przypadek, próbowałam znaleźć coś na ten temat w literaturze fachowej. Na nic nie natrafiłam. Pisano o zatruciach pracowników. Pojawiła się szczątkowa informacja o zatruciach ołowiem wśród dzieci w USA, które piły mleko od krów pasących się przy autostradach. Wtedy ołów był używany jako substancja przeciwstukowa w samochodach, emitowały go auta, był składnikiem benzyny. Potem pojawiły się doniesienia, że dzieci zdrapują ze ścian i zjadają farby zawierające ołów. Zatrucia, które miały niedawno miejsce we Francji, kiedy spaliła się katedra Notre Dame, też były zatruciami ołowiem. 
Sprawa nabrała rozgłosu - $\mathrm{u}$ nas francuskie normy ołowiu oznaczały pełne zdrowie.

L.S.: Zmieniły się skala, czasy i optyka postrzegania problemu związanego $\mathrm{z}$ ołowiem.

J.W.K.: Tak, zmieniła się skala. Kiedy słuchałam doniesień o zatruciach we Francji, myślałam: „Boże, o jakim poziomie zatrucia ołowiem oni mówią...”.

L.S.: Powróćmy jeszcze do postawy rodziców tych zatrutych dzieci. Rozumieli powagę sytuacji, mieli świadomość zagrożenia?

J.W.K.: Wszyscy rodzice optowali za leczeniem dzieci i podejmowaniem działań. Nikt się nie buntował, wierzyli mi. Pełne zrozumienie sytuacji. Z wszystkimi rodzicami rozmawiałam. Nikt $z$ moimi decyzjami nie dyskutował. Wszyscy przychodzili na spotkania, wszyscy mnie słuchali. Prosiłam, by przygotowali dzieci na wyjazd do sanatorium na przykład w piątek i tak też się działo. Nikt nie powiedział: „nie”. Respektowali moje prośby. Kiedyś chcieli zorganizować zebranie, poprosiłam ich, by tego nie robili. Istniała obawa, że władze zaczną bardziej interesować się tą sprawą. Nikomu to nie było potrzebne, rodzicom zawsze mówiłam prawdę. A władza zastanawiała się, jak wyciszyć temat. Byłam okropnie niepokorna. Życie przygotowało mnie, by być upartą, by bronić swojego zdania, żeby móc wszystkiemu zaradzić.

Pan Jędryka napisał, że huta dawała autobusy. Nic podobnego. Dzieci przebywały w sanatorium miesiąc, dwa, płakały z tęsknoty. Rodzice buntowali się i dopiero wtedy łaskawie huta fundowała autokary, żeby mogli je odwiedzić.

L.S.: Władze huty w końcu zainteresowały się losem dzieci i ich rodziców?

J.W.K.: W końcu musiały. W hucie sprawa stała się głośna, wszyscy wiedzieli. Zatrucie ołowiem wśród jej pracowników było duże. Badano im poziom koproporfiryny w moczu - oznaczało się go krzyżykami. Jeśli ktoś z pracowników miał cztery krzyżyki, to na dwa miesiące trafiał do huty cynku, żeby wypłukać nieco ołów. Kiedy osiągnęli poziom dwóch krzyżyków, wracali do swojej pracy. 
A nam zdarzały się i trzy krzyżyki u dzieci. Badaliśmy kwas delta-aminolewulinowy, koproporfiryny, morfologię, wyjątkowo ołów, gdyż to szpitale miały pierwszeństwo badań. Jedyny spektrofotometr był w Sosnowcu. Tam wożono materiał do badania poziomu ołowiu, musiałam więc się wycofać i bazować tylko na wynikach z naszych laboratoriów. Miałam już jednak porównanie, punkt odniesienia.

L.S.: A jakie zdanie na temat Pani działalności miała Pani najbliższa rodzina?

J.W.K.: Mąż pracował bardzo intensywnie u Profesora Franciszka Kokota ${ }^{17}$. Był zajęty własną pracą, ale po powrocie do domu także musiał mi pomagać. Mama pomagała mi najbardziej, przepisywała listy, które przygotowywała Pani Wiesia Wilczek. Wpisywała również wyniki do kartotek; gdy trzeba było coś przepisać, prosiłam o to mamę. W domu nikt nigdy nie powiedział „ale”. Nie było mowy o tym, że nie będę pracować i że nie będę pomagać dzieciom. Sama też zachowywałam się jak w amoku.

L.S.: Czy kiedykolwiek pomyślała Pani, że nie warto, że trzeba odpuścić, że cena jest zbyt wysoka, zwłaszcza po sprawie z doktoratem?

J.W.K.: Nigdy. Nie, nigdy. Profesor Franciszek Kokot po Radzie Wydziału powiedział: „Dziewczyno, odpuść sobie, nie zrobisz tego doktoratu”. Wniosek był taki, że musiano w tamtym czasie dyskutować na temat mojej dysertacji, sprawa ołowicy w Katowicach musiała w środowisku medycznym i naukowym Śląska wzbudzać zamieszanie. Po latach zapytałam Pana Profesora, co miał na myśli. Niestety nie pamiętał, że coś takiego powiedział.

${ }^{17}$ Franciszek Józef Kokot (ur. 24 listopada 1929 r. w Oleśnie, zm. 24 stycznia 2021 r. w Chorzowie) - lekarz, nefrolog i endokrynolog, profesor nauk medycznych, rektor Śląskiej Akademii Medycznej (1982-1984), członek rzeczywisty PAN i PAU, doktor honoris causa multi oraz laureat nagrody Lux ex Silesia w 2001 r. Autor lub współautor ponad 650 prac oryginalnych (z czego ponad 150 było publikowanych na łamach periodyków medycznych w Europie Zachodniej i Stanach Zjednoczonych), ponad 230 prac poglądowych, współautor 40 podręczników. Zob. https://nauka-polska.pl/\#/profile/scientist?id=46819\&_k=gem6t5 [data dostępu: 16.10.2020]. 
L.S.: Nie zastanawiała się Pani nad tym, że ktoś złamał Pani karierę naukową?

J.W.K.: Nie, wcale mi na tym nie zależało. Zaczęłam pracować normalnie, przyjmować wyniki z sanepidu, działałam jak zawsze.

L.S.: Nie kusiło Pani, by wrócić do przerwanej bez Pani woli i udziału sprawy obrony doktoratu? Zaszły duże zmiany na scenie politycznej, powstały warunki sprzyjające powrotowi do tematu.

J.W.K.: Nie, ale wzywano mnie, żeby poprawić, napisać. Doszłam do wniosku, że nie będę pisać od początku. Pierwsze notatki, najważniejszy, pierwotny tekst przygotowałam na maszynie, którą mam do dzisiaj. Nie było kopii, egzemplarzy dodatkowych. Wyjmowałam kartki z tej pracy, wkładałam nowe z innym tekstem, zgodnie $\mathrm{z}$ sugestiami promotorki, wyrzucałam całe fragmenty - nic z pierwszej wersji nie zostało. Nie miało sensu, bym wracała do tematu, praca była za bardzo rozczłonkowana, rwana, fragmentaryczna. Pisać ją od początku po dziesięciu latach... nie.

L.S.: Ówczesna Śląska Akademia Medyczna wykonała jakiś ruch, by podjęła Pani próbę kontynowania procedury uzyskania stopnia doktora?

J.W.K.: Profesor Jerzy Żmudziński ${ }^{18}$ próbował, ale ciągle uważałam, że jest to działanie pozbawione sensu. Najważniejsze wyniki musiałam wyrzucić z dysertacji. Niektóre spisy wyników dzieci mam do dzisiaj, ale w kilku brakowało informacji o poziomie ołowiu. Doktorat nie był mi potrzebny. Nosiłam w sobie potrzebę pomocy dzieciom, naprawdę. Ogromną satysfakcję dawała mi wiedza, że udało się jakieś dziecko przesiedlić. Profesor Bożena Hager-Małecka zała-

${ }^{18}$ Wydaje się, że autorem odręcznej notatki datowanej na 5 maja 1982 r., której kserokopia wraz z innymi kopiami dokumentów została przekazana UŚ przez SUM, jest prof. Jerzy Żmudziński. W piśmie odnotował on: „Jesienią 1980 roku, bezpośrednio po odwołaniu Rektora J. Jonka, poprosiłem p. Prof. Hager-Małecką o spowodowanie, by lek. Jolanta Król uzupełniła pracę [...]. W trakcie długiej rozmowy, nie ujawniła chęci (mimo nalegań z mojej strony) na uzupełnienie pracy i kontynuowanie przewodu doktorskiego". 
twiła u Ziętka ${ }^{19}$, który był w tamtym czasie bardzo pozytywną osobą, osiem mieszkań w starym budownictwie. Ziętek był swego rodzaju buforem. Ojciec Pani Profesor, Hager ${ }^{20}$, walczył razem z nim w powstaniu. Potem były mieszkania w Siemianowicach, Michałkowicach, sporo rodzin na własną rękę znalazło mieszkania i przeprowadziło się. Huta zbudowała osiedle - wtedy nazywało się Rybki, teraz zwane Morawa. Miały tam powstać mieszkania dla hutników, a zatem w pierwszej kolejności musieli przyznać je ludziom z chorymi dziećmi. Dyrektor ds. socjalnych chwytał się za głowę, gdyż ustawiały się do niego wielkie kolejki robotników, którzy mieli chorych nawet troje dzieci. Włączyłam się w sprawę, bo zrobiłam listę dzieci, które najpilniej muszą się wyprowadzić. Ustalałam ją według liczby dzieci chorych w rodzinie, poziomu zaawansowania choroby i długości pobytu w sanatorium. Oddałam listę do huty i pokazałam ją ludziom. Nikt do mnie nie miał pretensji, a trzeba pamiętać, że były ciężkie czasy, otrzymanie mieszkania graniczyło z cudem. W tej chwili mam takich - że tak powiem - „ołowików”, od których komornik ściąga czynsz ze starego budownictwa, bo na przykład matka dostała przydział na mieszkanie, potem dzieci (było ich, powiedzmy, ośmioro) zostały i płaciły czynsz do momentu zwolnienia ich ze spółdzielni inwalidów. Jeszcze to muszę załatwić, żeby Urząd Miasta odstąpił i wycofał od komornika roszczenia za ten zaległy czynsz. To są ludzie ciężko chorzy, ludzie nieporadni, choć nie życzą sobie,

${ }^{19}$ Jerzy Jan Antoni Ziętek, ps. Jorg (ur. 10 czerwca 1901 r. w Gliwicach, zm. 20 listopada 1985 r. w Zabrzu) - polski polityk, urzędnik, samorządowiec, działacz partyjny, państwowy i społeczny oraz wojskowy. Generał brygady Sił Zbrojnych Polskiej Rzeczypospolitej Ludowej, członek Komitetu Centralnego PZPR (1964-1981), przewodniczący prezydium Wojewódzkiej Rady Narodowej w Katowicach (1964-1973), wojewoda śląski (1945), wojewoda katowicki (19731975), członek Rady Państwa (1963-1985, w tym od 1980 r. zastępca przewodniczącego); poseł na Sejm III kadencji w II RP, na Sejm Ustawodawczy oraz na Sejm PRL II-VIII kadencji. Prezes Związku Weteranów Powstań Śląskich, wiceprezes Rady Naczelnej Związku Bojowników o Wolność i Demokrację (1949-1985), członek Ogólnopolskiego Komitetu Frontu Jedności Narodu. Zob. A. Topol: Jerzy Ziętek: 1901-1985. Generał, wojewoda, mąż stanu. Katowickie Towarzystwo Społeczno-Kulturalne, Katowice 1986; J. Walczak: Jerzy Ziętek. Biografia Ślązaka. Śląsk, Katowice 2002.

${ }^{20}$ Bronisław Hager (ur. 30 stycznia 1890 r. w Miłosławiu, zm. 30 czerwca 1969 r. w Tarnowskich Górach) - lekarz, działacz niepodległościowy i społeczny. Zob. M. Karnówka, J. Stomska: Bronisław Hager: lekarz, społecznik, samorządowiec. [b.w.], Tarnowskie Góry 2004. 
by tak o nich mówić. Mają pretensje do redaktorki z „Gazety Wyborczej”, że tak o nich powiedziała. Obrażają się, a są nieporadni życiowo. Nie potrafią załatwić wielu rzeczy.

L.S.: Ma Pani stały kontakt $\mathrm{z}$ „ołowikami”?

J.W.K.: Niewielki. Kłaniają mi się, gdy idę przez Szopienice. Niektórych już nie poznaję, ale oni mnie jeszcze tak. Kilka osób, które kojarzę z imienia i nazwiska, widzę wśród udzielających się na moim profilu na Facebooku, szczególnie mężczyzn - gratulują mi, komentują doniesienia medialne. Nie zaglądam ostatnio do FB, bo nie mam czasu.

L.S.: Coś niesamowitego, Matka Boska szopienicka na Facebooku!

J.W.K.: Staram się być na bieżąco. Dzieci mnie mobilizują, pisząc e-maile, wysyłając zdjęcia. Czasami zgrywam je na pendrive’a i oddaję do wywołania.

L.S.: Czy gdyby mogła Pani cofnąć czas, to postąpiłaby Pani inaczej? Czy inaczej pokierowałaby Pani pewnymi sprawami?

J.W.K.: Nie. Nie cofnęłabym się nigdy, robiłabym to, co robiłam. Ale miałam wokół sprzyjające mi osoby, bo przecież nie działałam sama, sama nie mogłabym niczego zrobić. Wspierało mnie spore grono ludzi: laborantki, pielęgniarki, ludzie dobrej woli. Pani Wiesia Wilczek bardzo się poświęciła i pracowała ze mną jak w amoku. Potem odeszła z zawodu. Jestem i byłam osobą wymagającą, ogólnie wszystko musi grać. Musiałam być poinformowana na bieżąco, komplet danych musiał być wpisany. W pewnym momencie wszystko się skończyło, a zarobki w służbie zdrowia stały się bardzo niskie. I wtedy Pani Wiesia odeszła, ale utrzymuję z nią kontakt. A ja pracowałam długo, skończyłam pracę w 2012 roku. Pewnie gdybym wtedy poszła na dłuższy urlop, to wróciłabym do zawo$\mathrm{du}$, a nie przeszła na emeryturę. Żałuję, że zrezygnowałam z pracy. Nigdy nie cofnęłabym swoich decyzji, a myślę nawet, że za mało wojowałam.

L.S.: Naprawdę? Cóż jeszcze chciałaby Pani zwojować? 
J.W.K.: Generalnie, za mało zwojowałam. Kiedy sanepid opanował sytuację i wziął sprawę w swoje ręce, to zaczęłam się powoli wycofywać...

L.S.: A pewnie można było jeszcze docisnąć...

J.W.K.: Tak, można było. Już nie diagnozowaliśmy tak chorych dzieci, jak wtedy, kiedy zaczynałam badania. $Z$ najbliższego sąsiedztwa odnotowywaliśmy do tysiąca dzieci, pozostałe miały podwyższone wartości. Poziom higieny wzrósł, a ołów był wchłaniany zwłaszcza przez przewód pokarmowy. Dzieci brudnymi rękami zjadały na podwórku bułki razem $\mathrm{z}$ ołowiem. W dalszym sąsiedztwie stało osiedle, na którym mieszkania miały łazienki, zupełnie inne - lepsze - warunki socjalne. Najgorzej było w familokach, gdzie ubikacje były na zewnątrz.

L.S.: Czy jakaś historia dziecka szczególnie utkwiła Pani w pamięci?

J.W.K.: Dużo tych historii pamiętam, wiele dzieci. Miałam nawet pomysł, żeby teraz wezwać kilka osób, które były wtedy dziećmi, i teraz zrobić im badanie poziomu ołowiu. $\mathrm{W}$ ich ciałach na pewno pozostał ołów. Kiedy pomyślę o tych ciężko chorych dzieciach, kiedy przypomnę sobie, ile spośród nich zmarło przed pięćdziesiątym rokiem życia, to myślę, że źle się działo.

Nikt nie zdawał sobie sprawy, że to tak negatywnie wpływa na układ nerwowy, nie mówiąc już o wszystkich innych tkankach czy kościach. Centralny system nerwowy był bardzo obciążony. Wraz z hutą powstała szkoła specjalna. Sporo dzieci z tamtego rejonu do niej chodziło. Nikt tego nie udowodnił, ale jest jakaś zależność przyczynowo-skutkowa. Być może bałabym się dotrzeć do tamtych ludzi, ale gdybym się uparła, to wszystko jest możliwe. Nawet mężowi mówiłam, że na własny koszt zrobiłabym teraz tym ludziom badania. Współcześnie taka akcja nie mogłaby mieć miejsca, pytano by: kto zrobi badania? za ile? kto zlecił? czy pilne? po co? Wszystko trzeba przeliczać. Gdybym zapłaciła $\mathrm{z}$ własnych pieniędzy, nikt by nie pytał, po co to robię.

L.S.: Może to temat i czas na pogłębione badania, analizę, podjęcie tematu badawczego? 
J.W.K.: Na pewno poziom ołowiu w organizmach tych ludzi wciąż jest wysoki, nie wypłukał się jeszcze. Widzę to po chorobach, na jakie zapadają. Pytam czasem rodzinę o to, na co zmarli. Najczęściej otrzymuję odpowiedź: „W zasadzie nie wiadomo na co". Nie chcę w to wnikać, bo jest mi smutno. Dużo teraz by można mówić o tamtych dzieciach. Nie chcę podejmować tego tematu, by nie sprawić tym ludziom przykrości.

L.S.: Zawsze chciała Pani zostać lekarzem? Co popchnęło Panią w kierunku medycyny? Kilkukrotna zmiana szkoły chyba nie pomogła wykształcić w Pani chęci do edukacji i studiowania?

J.W.K.: Chyba coś w głowie musiałam jednak mieć, że przy zmianie szkół i lekkim podejściu do nauki 11 maja 1956 roku zdałam maturę. Pojechałam wtedy z ośmioosobową grupą z mojej klasy - liceum skończyłam w Siewierzu zapisać się na uczelnię do Rokitnicy ${ }^{21}$. Kiedy tam dotarłam, ogarnęło mnie przerażenie. Dowiedziałam się, że tylko jeżeli nauczę się z grubej książki, to zdam chemię, a ja uczyłam się z trzech cieniutkich, które można było „na pałę" wykuć. Zdawałam chemię, fizykę oraz naukę o konstytucji i świecie współczesnym. I dopiero wtedy zaczęłam się tak naprawdę uczyć, tak na poważnie. Po tym wyjeździe zdałam sobie sprawę, że ze swoją wiedzą nie mam czego szukać na studiach. Wiedziałam, że muszę zacząć się uczyć, bo książeczki, z których korzystałam w liceum, zawierały zbyt mało wiedzy. Jak dzisiaj pamiętam stoisko z książkami, gdzie stał pewien człowiek, którego poznałam już po studiach. Powiedział: ,jak się nauczysz z tej książki, to zdasz egzamin na studia”. Kupiłam ją. A ponieważ wielu rzeczy nie rozumiałam z tej chemii, jeździłam do kuzynki, która była adiunktem na Politechnice Śląskiej. Pracowała, ale w wolnych chwilach tłumaczyła mi to, czego nie rozumiałam. Wryłam tę książkę. Fizyki też się tam uczyłam. Czyli od 12 maja zaczęłam się uczyć, a 2 lipca zdawałam egzamin wstępny. Uczyłam się całymi dniami, w ogóle nie wyściubiałam nosa z pokoju. Egzamin zdałam dobrze i dostałam się na studia. $\mathrm{Z}$ tych ośmiu osób dostały się trzy. Wtedy było siedem osób na jedno miejsce. Bardzo trudno było się dostać.

\footnotetext{
${ }^{21}$ Rokitnica - dzielnica Zabrza od $1951 \mathrm{r}$.
} 
L.S.: Od początku miała być pediatria?

J.W.K.: Nie, chciałam być chirurgiem. Chirurgia była moim marzeniem, ale będąc na stażu - a staż odbywaliśmy na czterech oddziałach: chirurgia, interna, pediatria i ginekologia - stwierdziłam, że interna mi nie odpowiada, a na chirurgii nie mogłam być, gdyż wtedy robiło się na anestezjologii tzw. kapanki, czyli eterem kapało się na maskę i pacjent spał. Ten eter mnie usypiał, na sali operacyjnej byłam taka błędna. Bardzo szybko na mnie działał. Zdałam sobie sprawę, że nie mogę być chirurgiem. I zostałam na pediatrii, która mi od początku bardzo odpowiadała. Panowała tam świetna atmosfera, byli fajni ludzie, dużo się można było nauczyć. I tak już zostało - pediatria.

L.S.: Dzięki temu, że zdecydowała się Pani na pediatrię, szopienickie dzieci wygrały los na loterii.

J.W.K.: Innym razem mogłybyśmy poruszyć temat tego, dlaczego szopienickie dzieci musiały być takie chore. Miałam ogromną satysfakcję, kiedy dzieci wyprowadzały się z Szopienic, gdy wracały z sanatorium i matki miały przydziały do nowych mieszkań. Pamiętam, że spisywałam adresy, dokąd kto się wyprowadza. Pani Wiesia mówiła, że byłam jak huragan. Miałam dużo energii i siły, niczym się nie przejmowałam. Nic mnie nie powstrzymało przed działaniem na rzecz chorych dzieci z Szopienic.

L.S.: Jest Pani kobietą pełną sprzeczności albo - lepiej powiedzieć - łączącą żywioły nie do połączenia: wulkan, energia i haftowanie.

J.W.K.: Do tej pory nie używam żadnych środków uspokajających. Nawet ostatnio, w bardzo trudnych chwilach po śmierci męża, z którym przeżyłam sześćdziesiąt lat dobrego małżeństwa. Nigdy nie byliśmy osobno, wszystkie wczasy i urlopy spędzaliśmy razem, na ile mogliśmy i na ile było to możliwe, zjeździliśmy świat.

L.S.: A jak mąż - również lekarz - oceniał Pani szopienicką aktywność, akceptował to, co Pani robi? 
J.W.K.: Tak, ale też ja akceptowałam to, co on robił. Taka sytuacja: mieliśmy remont $\mathrm{w}$ domu, bo przeprowadzaliśmy się z Dąbrówki - również mieszkałam blisko huty - do innego mieszkania, w centrum Katowic. Musieliśmy się przeprowadzić i dopiero potem robić remont. Poprosiłam małżonka, żeby wziął kilka dni urlopu, żebyśmy mogli to jakoś ogarnąć. Mąż poszedł do Profesora Kokota z prośbą o urlop, by zorganizować i przeprowadzić remont w mieszkaniu, a Profesor na to: „Co? Na remont w domu ty chcesz wolne? Nie, mój drogi, masz dwa poważne referaty wygłosić, idź do biblioteki i ucz się, a żona da sobie radę". Profesor Kokot zawsze taki był! ${ }^{22}$ Nie było mowy, że mąż powie, że musi zająć się domowymi obowiązkami. Ważniejsza od trosk życia codziennego dla Profesora była nauka, wygłaszanie referatów.

L.S.: I Pani została $\mathrm{z}$ remontem sama.

J.W.K.: Tak. I dałam sobie radę.

L.S.: $\mathrm{W}$ to nie wątpię, Pani Doktor. Huragan zawsze daje sobie radę: i z remontem, i z pracą zawodową, i z szopienicką hutą.

J.W.K.: Coś w tym jest, egzamin na prawo jazdy zdałam po czterech lekcjach. Eksternistycznie. Nie jeździłam wcześniej, byłam tylko pasażerem. Mąż mówił: „Ty i prawo jazdy? Daj spokój”. Uparłam się, że zrobię szybko, i tak się stało. Jestem uparta. Jak mam coś zrobić, to muszę to skończyć. Nawet jeśli mi coś nie pasuje, na przykład w haftach. Nie pasuje mi jakiś haft, jest nieładny, nie wyjdzie i nie będzie dobry, ale go zaczęłam, więc muszę skończyć. Teraz, po śmierci męża, też muszę sobie dać radę. Mieliśmy podział obowiązków, mąż zajmował się ogrzewaniem domu. Uczę się teraz tego wszystkiego: czy to palić w kominku, czy to kosić trawę. Mam sześcioro wnuków - w tym trzech męż-

${ }^{22}$ Prof. dr hab. n. med. Jan Duława w przytoczonych anegdotach o Profesorze Kokocie dał wyraz jego nietuzinkowej osobowości i charyzmie. Opowieści potwierdzają spostrzeżenia zawarte w słowach Pani Doktor Jolanty Wadowskiej-Król. Por. http://70lat.sum.edu.pl/index. php/2018/01/30/anegdoty-zwiazane-z-prof-dr-hab-n-med-franciszkiem-kokotem/ [data dostępu: 12.10.2020]. 
czyzn - cały czas pytają, w czym mogą pomóc. Odpowiadam: „nie, nie, sama to zrobię". Muszę sama się wszystkiego nauczyć.

L.S.: Pani Doktor, dziękuję za rozmowę i życzę, by energia, siła oraz zdrowie Pani nie opuszczały.

Lucyna SAdZIKowska - dr hab., prof. UŚ, literaturoznawczyni, członkini redakcji rocznika naukowego „Narracje o Zagładzie” i zespołu redakcyjnego czasopisma „Bibliotheca Nostra”. Autorka monografii: Szukanie kluczy. O literaturze poobozowej Gustawa Morcinka (2017) oraz Listy z lagrów i więzień 1939-1945. Wybrane zagadnienia (2019). Z prof. Krystyną Heską-Kwaśniewicz opracowała i wstępem opatrzyła tom Listy $z$ Dachau. Gustaw Morcinek do siostry Teresy Morcinek (2016; nominacja do Nagród Historycznych „Polityki” w kategorii wydawnictw źródłowych). W 2019 roku ukazała się publikacja Działalność poselska Gustawa Morcinka, czyli katalog ludzkiej biedy. Dokumenty w opracowaniu Krystyny Heskiej-Kwaśniewicz i Lucyny Sadzikowskiej, a w 2020 roku Głosy z "Ostatniego kręgu”: korespondencja $z$ Konzentrationslager Auschwitz Józefa Kreta i Zofii Hoszowskiej-Kretowej (nominacja do Nagród Historycznych „Polityki” w kategorii źródła).

(D) https://orcid.org/0000-0002-5509-4513 